\author{
Anetta Luto-Kamińska \\ Toruń
}

\title{
TOŻSAMOŚĆ KULTUROWA (RELIGIJNA) A WYBORY TŁUMACZA
}

\begin{abstract}
Zarys treści: W artykule poruszono problem wpływu kultury środowiskowej, a przede wszystkim religii, na pracę tłumacza, czego efektem są jego świadome wybory w kształtowaniu tekstu przekładowego. Owe ingerencje można rozpatrywać na różnych poziomach, dotyczą bowiem kwestii leksykalnych, gramatyczno-stylistycznych, a nawet treściowych. Ingerencja w warstwę treściową tłumaczonego dzieła może przybierać rozmaite formy. Tu skupiono się na środkach językowych, którymi translator operuje, by tekst mógł się wpisać w kulturalno-religijny nurt jego epoki. Omawiane utwory pochodzą głównie z XVI w.
\end{abstract}

W pływ tłumacza na oryginalny utwór w procesie jego translacji to problem wielokrotnie już podejmowany i szeroko analizowany przez badaczy. Tłumaczenie jest niewątpliwie procesem niezwykle złożonym, dotyczy bowiem nie tylko przełożenia tekstu zapisanego w jednym języku na tekst zapisany w innym języku, ale także transpozycji całej gamy zjawisk pozajęzykowych. Tekst oryginalny, który wyrósł w specyficznych warunkach kulturowych, zapisany przez człowieka przez te warunki ukształtowanego (światopogląd, wierzenia religijne, tożsamość społeczno-polityczna, znajomość tradycji itd.) trafia $\mathrm{w}$ ręce tłumacza mającego zwykle zupełnie inne korzenie, ukształtowanego przez odmienną kulturę. To od tego, jak dogłębna jest znajomość tej wieloaspektowej odmienności, zależy powodzenie autora tłumaczenia. Daje on nam możliwość obcowania z prawie takim samym tekstem, który zapisał twórca, i w tym miejscu zaczyna się już rola czytelnika-odbiorcy oraz jego kompetencji, na ile rozszyfruje wszelkie odniesienia pozajęzykowe, kulturowe zakodowane $\mathrm{w}$ tym dziele. To oczywiście jedna z możliwości, jaką daje tłumaczowi praca $z$ oryginałem. Może on pójść zupełnie inną drogą, a mia- 
nowicie dokonać wieloaspektowej transpozycji dzieła na utwór, który w wielu dziedzinach odejdzie od podłoża kulturowo-tożsamościowego swojego oryginału, a wkomponuje się w rzeczywistość kulturową tłumacza i odbiorcy.

Dla mnie podstawą do dalszych rozważań będzie taki typ pracy tłumacza, w którym uwidocznia się konieczność oddania przez niego realiów obcych jego kulturze, nierzadko obcych też jego systemowi językowemu. Skupię się na tekstach staropolskich, głównie z XVI wieku, na których tłumaczeniu szczególne piętno odcisnęła religia. Jej znaczący wpływ, zarówno na płaszczyźnie formalnej, jak i treściowej, przedstawię w kilku aspektach.

Wiek XVI - określany w historii języka początkiem okresu średniopolskiego - przyniósł cztery pełne tłumaczenia Biblii oraz kilkakrotnie więcej przekładów jej fragmentów, zarówno katolickich, jak i innowierczych. Teksty te wykazują znaczne zróżnicowanie językowe, w tym także pod względem stylistycznym i leksykalnym, co wynika z przyjętych przez translatora założeń, popierania konkretnej doktryny religijnej, większej lub mniejszej świadomości i językowej, i kulturowej, dotyczącej tekstu oryginalnego. Wszyscy tłumacze Pisma św. stanęli przed tym samym problemem: przełożenie tekstu religijnego stanowiącego podstawę wiary przy jednoczesnym oddaniu całego wachlarza realiów, często dalekich polskiej kulturze. Złożoność tego zagadnienia wynika z wielu czynników. Dotyczy to chociażby konieczności oddania realiów, niekiedy całkowicie obcych naszej szerokości geograficznej, i nie chodzi tu wyłącznie o kwestie świadomości i wiedzy, ale także o możliwości językowe, dla wielu bowiem zjawisk brakowało jeszcze adekwatnego słownictwa.

Niewątpliwym wyzwaniem w procesie przekładu były kwestie leksykalne. Tłumacz musiał znaleźć polski odpowiednik słowny nawet wówczas, gdy desygnat był w naszej kulturze nieznany. Biorąc za przykład Biblię Budnego, zauważymy, z jaką pieczołowitością autor starał się znaleźć jak najlepsze sposoby oddania oryginału, wielokrotnie zamieszczając rzeczowe komentarze na marginesie. W księdze Genesis arkę, którą zbudował Noe, nazywa skrzynia, a materiał, z którego została zbudowana - drzewem goferowym (Gen 6/14), co następnie objaśnia na marginesie: „Zostawiło się słowo hebrajskie, że je różnie przekładają, inszy cedrem, inszy sosną, inszy jodłą albo świerkiem.”

Poza znalezieniem adekwatnych odpowiedników dla apelatywów należało w sposób wyważony podejść również do nazw własnych, które często - oprócz tego, że coś identyfikowały przez nazwanie - miały swoją logiczną motywację w językach oryginalnych, która w przekładzie ulegała zatarciu (por. Kwilecka 2003b: 295-297, Zarębski 2004, 2007). W tłumaczeniach nomina propria mogły zatem pojawiać się w swej oryginalnej formie, bądź 
to $\mathrm{w}$ postaci zupełnie niezmienionej, translokowanej, bądź zaadaptowanej do polskiego systemu gramatycznego pod względem fonetyczno-morfologicznym. Translator mógł również pójść dalej i podjąć się przetłumaczenia obcej nazwy własnej na język polski z zachowaniem zawartych w niej treści. Oczywiście ta ostatnia możliwość niosła za sobą największe ryzyko i była też największym wyzwaniem (Cieślikowa 1996). Rozszyfrowanie, jaką drogą szły skojarzenia XVI-wiecznego tłumacza, bywają niekiedy trudne do uchwycenia dla odbiorcy współczesnego. Dla przykładu: wspomniany już Szymon Budny w Proroctwie Amosa (6/14) na oddanie biblijnej nazwy ha-araba (hebr. 'pustynia') użył wyrażenia potok puszcze, co dodatkowo uściślił w uwadze marginesowej jako równina puszcze. Trudno jednak orzec, czym kierował się autor tłumaczenia w swym wyborze apelatywów tworzących tu zestawienie $\mathrm{w}$ funkcji proprialnej nazwy miejsca, odnoszące się zapewne do dzisiejszego potoku wadi el-Hesa lub wadi el-Araba. Generalnie Budny starał się obce nazwy własne (osobowe i miejscowe) pozostawiać jednak w brzmieniu hebrajskim, dodając do nich szersze komentarze na marginesach, jak np. w objaśnieniach semantyki imion w księdze Genesis dla Kain: „Kain wykłada się dzierżawa abo dzierżany” (marg. do Gen 4/1) lub Hewa: „Żydowie polscy dzisiejszy czytają Chawah. Wykłada się żywa albo żywąca" (marg. do Gen $3 / 20$ ). W wielu wypadkach takie komentarze ułatwiają zrozumienie samego tekstu biblijnego, jak to jest w ostatnim cytacie, ponieważ tekst wersetowy nawiązuje do pierwotnej warstwy znaczeniowej nazwy osobowej: „I nazwał Adam imię żenie swej Hewa, iż ona jest matką każdego żywego" (Gen 3/20).

Na przekładzie piętno odciskała również stylistyka oryginału oraz środki językowe, którymi dysponuje dany język, co tłumacze starali się oddać różnego rodzaju transpozycjami językowymi, jak np. hebrajski superlativus w postaci: Pan nad Pany, Król królów itp. Pewne zabiegi translacyjne ukształtowały z biegiem czasu charakterystyczny, rozpoznawalny styl biblijny, który jest konsekwencją świadomych wyborów tłumacza oraz tego, na ile zaproponowane przez niego transpozycje obcych wzorów stylistycznych zadomowiły się w języku. Dla przykładu: w Ewangeliach, dla których podstawowym znaczącym elementem przekazu treści są przytoczenia (słów Jezusa i innych osób), widać wyraźnie, jak do polszczyzny wprowadzono obce struktury leksykalno-gramatyczne, które były zwykle, choć nie zawsze, możliwie wiernym odzwierciedleniem właściwości składni oryginału. W wydanym w 1593 r. przekładzie Nowego Testamentu J. Wujka, który w dużej mierze podążał za wzorcami translacyjnymi wskazanymi przez św. Hieronima w Wulgacie, uwidacznia się silna zależność od łacińskiego oryginału w syntaktycznej i leksykalnej organizacji zapowiedników przytoczenia. Danuta Kowalska (2007) 
poddała analizie sposoby wprowadzania mowy niezależnej w Ewangelii wg św. Marka, określając ich typy, a także zwracając uwagę na miejsca, w których mamy do czynienia ze świadomą modyfikacją tłumacza. Obok zapowiedników w formie zdań prostych typu zaprawdę powiedam wam (ci) (w tym wypadku będącego kalką łac. amen dico vobis (tibi)), w których występujący czasownik autorka określa mianem performatywnego, znajdziemy liczne struktury syntaktyczne z użyciem kilku form werbalnych. Do takich zaliczyć można konstrukcje pleonastyczne z użyciem dwóch czasowników mówienia w połączeniu szeregowym typu odpowiedziała i rzekła (respondit et dicit) oraz konstrukcje czasownikowo-imiesłowowe typu odpowiedział mówiąc (respondit dicens), wołali mówiąc (clamabant dicens) oraz odpowiedziawszy rzekł (respondens ait), zawoławszy rzekt (exclamans aiebat), a nawet odpowiedziawszy mówit nauczając (respondens dicebat dicens). W ostatnim typie widać dodatkowo transformację nazywanej przez imiesłów czynności z uprzedniej na równoczesną. Wart zasygnalizowania jest fakt, że wskazane połączenia tautologiczne z imiesłowem stały się w XVI w. tak charakterystycznym dla stylu biblijnego sposobem konstruowania wprowadzeń oratio recta, że pojawiały się również tam, gdzie tekst oryginalny nie zawierał formy participium, tylko indicativum, np. opowiedział mówiąc jako tłumaczenie szeregu respondit et dixit (Mar 15/9). Co ciekawsze, tego typu struktury wykorzystywane były także w innych tekstach religijnych, które nie były tłumaczeniami, np. woła powiedając, powiedać raczy mówiąc (Postylla M. Reja (1566), A5, 252), a nawet w pismach świeckich: szeptał powiadając (Kronika M. Bielskiego (1564), 401v), powiadat rzekac (Historyje rzymskie (1566), 131). Oczywiście prezentowane zwroty imiesłowowe, mające swe źródło w hebrajskiej stylistyce, licznie pojawiają się również w innych częściach i innych tłumaczeniach Biblii, nie są też ograniczone wyłącznie do przedstawionych struktur wprowadzających mowę niezależną. Wśród tautologicznych konstrukcji znajdziemy także połączenia imiesłowowe typu błądził bładząc (Biblia Budnego (1572) Ez 44/9) lub - utworzone na podobnej zasadzie - wyrażenia typu służac stużbe (ibidem $E z$ 44/11).

Wiek XVI przyniósł zatem wielką różnorodność pod względem technik przekładowych tekstów biblijnych: zarówno wierne - verbum de verbo - jak np. Biblia Budnego, swobodne, jak Biblia Radziwiłłowska, czy artystyczne, jak np. Psałterz Kochanowskiego ${ }^{1}$.

${ }^{1}$ Szczegółowa charakterystyka języka polskich Biblii XVI-wiecznych i późniejszych to temat wielu opracowań; zob. m.in. Pepłowski (1978), Cybulski (1996), Bieńkowska (1999), Moszyński (2003), Kwilecka (2003a), Lisowski (2010). 
Przekład tekstów religijnych, zwłaszcza tych, które stanowią podstawę wierzeń, jest dla tłumacza niewątpliwym wyzwaniem, spoczywa na nim bowiem wielka odpowiedzialność wykraczająca w swej ostatecznej ocenie poza kwestie rzetelności i adekwatności, a rozpatrywana w aspektach etyczno-kulturowych, a także kultycznych. Ta konstatacja dotyczy nie tylko polskich translacji Biblii, ale również innych tekstów wiary, np. Koranu, którego pierwszy polski przekład powstał w XVI wieku, a znany jest z późniejszych odpisów. Zasada idżazu nie dopuszczała możliwości tłumaczenia świętej księgi islamu na języki obce, jednak - głównie z powodów praktycznych, a takim był raczej powszechny brak znajomości języka arabskiego w społeczności Tatarów Wielkiego Księstwa Litewskiego - przekład taki powstał, przybierając zewnętrzną formę tefsiru, czyli komentarza tekstu koranicznego ( $\mathrm{z}$ ar. tafsir 'komentarz'), w rzeczywistości będąc jego wierną translacją².

Problem wpływu religii kształtującej światopogląd XVI-wiecznego translatora nie zamyka się jedynie w kwestiach technicznych związanych z przekładem tekstów wiary, ale dotyczy także jego wyborów, prowadzących nierzadko do znaczących transformacji oryginału, w wypadku tłumaczenia tekstów świeckich znacznie kłócących się z chrześcijańskim obrazem świata. Na przykładzie specjalnie wybranego tekstu przekładowego z połowy XVI w. wskażę, jak dalece mogły pójść prace modyfikacyjne mające na celu zaadaptowanie utworu powstałego w odmiennym kręgu kulturowo-religijnym.

Doskonałą egzemplifikację naświetlonego problemu stanowi podręcznik do nauki łaciny dla młodzieży szkolnej autorstwa Mateusza z Kęt pt. Ex P. Terentii comediis Latinissmae colloquiorum formulae..., nazywany dalej Rozmówkami³. Książka ma właśnie formę rozmówek, jej charakterystyczną cechą jest natomiast to, że tekst obcy, laciński, nie został spreparowany przez autora, tylko zaczerpnięty z oryginalnego tekstu literackiego - komedii Terencjusza. Wybór fragmentów również nie pochodzi od autora podręcznika, a jest przedrukiem pracy Caiusa Corneliusa Grapheusa noszącej ten samy tytuł. Mateusz z Kęt pod każde zacytowane zdanie, wyrażenie bądź dłuższą frazę rzymskiego poety podkładał linearnie jego polski ekwiwalent. Co do techniki przekładowej, należy zwrócić uwagę, że z jednej strony autor próbował przekazać we własnym języku treść zawartą we fragmencie oryginalnym, z drugiej

2 Pierwszy polski przekład Koranu nie doczekał się dotąd całościowej analizy językowej, lecz sam problem przekładów religijnego piśmiennictwa arabskiego stał się tematem licznych opracowań naukowych badaczy kitabistów. Zob. np. Łapicz (1986), Drozd (1999), KulwickaKamińska (2006).

${ }^{3}$ Szczegółowy opis języka utworu stanowił podstawę opracowania monograficznego, zob. Luto-Kamińska (2010). 
- dbał o wartości artystyczne i dydaktyczne swojej pracy. Ponieważ przekładał tekst niezwykle bogaty w aforyzmy, oddawał je bądź w sposób literalny, bądź używając znanych sobie polskich przysłów, które nie stanowiły dosłownego tłumaczenia, lecz niosły tę samą treść logiczną. Poza tym - ze względu na przeznaczenie utworu - starał się na tyle zaingerować w treść przekładanych fragmentów, by nie siać zgorszenia wśród młodzieży. Zgrabnie unikał wobec tego ścisłego przekładu partii mówiących o nierządnicach, stręczycielach czy związkach pozamałżeńskich. Tę samą linię zachował w czasie tłumaczenia tych fragmentów, które związane były z antycznymi wierzeniami i kulturą, a zdecydowanie odbiegały od chrześcijańskiej wizji świata człowieka żyjącego w XVI w. oraz od kulturowego tła epoki.

Ciekawie przedstawiają się w pracy te fragmenty, w których autor próbował oddać sens aforyzmu w sposób nieliteralny, manipulując przy tym odpowiednio motywami religijnymi. Dla przykładu łacińskie zdanie z Andrii: Omnis res iam in vado, co w dosłownym tłumaczeniu brzmi: Wszystko jest już na plytkiej wodzie, czyli jest bezpieczne, w podręczniku zostało oddane za pomocą przysłowia mającego ten sam sens przenośny: Już jedno Boga, kiedy doma noga $(\mathrm{R})^{4}$. Polska paremia nie jest oczywiście tłumaczeniem, lecz trafnie dobranym ekwiwalentem, bazującym na tym samym znaczeniu metaforycznym: 'jest dobrze, w porządku'. Podobnie postąpił tłumacz w wypadku fragmentu z Phormio: Quod fors feret, feremus aequo animo [= Co los przyniesie, zniesiemy ze spokojem], włączając i tu w polskim ekwiwalencie motyw boski: Czym nawiedzi przygoda, pamiętaj cirzpieć [tj. cierpieć - ALK] dla Boga. (S4v). Odwołania religijne są tu jednoznaczne - dotyczą Boga chrześcijańskiego, co zdecydowanie nie mieści się w realiach świata przedstawionego oryginału, wplata się natomiast w światopogląd tłumacza oraz realia kulturowe jego epoki. Kiedy Mateusz miał przetłumaczyć z kolei zdanie Credebas dormienti, haec tibi cofecturos deos, w którym odzwierciedlały się wierzenia antyczne, wolał po raz kolejny posłużyć się ekwiwalentem funkcjonalnym. Łacińskie pytanie z komedii Adelphoe: Myślałeś, że podczas twojej drzemki załatwia to za ciebie bogowie? oddał zatem polskim przysłowiem Przez ['bez' - ALK] prace nie będą kołacze (S), dokonując tym samym dokładnie odwrotnego zabiegu - rezygnacji z motywu religijnego jako obcego własnej kulturze duchowej. Identycznie postąpił, tłumacząc łacińskie przekleństwo Dii te

${ }^{4}$ Wszystkie polskie cytaty z Rozmówek podane są w transkrypcji, zapis łaciński został nieznacznie tylko zmodernizowany i poprawiono $\mathrm{w}$ nim oczywiste błędy. W nawiasie po cytowanym fragmencie polskim umieszczono jego lokalizację w tekście. O ile przy jego łacińskim odpowiedniku nie zapisano inaczej, pochodzi on z tej samej strony tekstu oryginalnego. 
eradicent [= Niech cię bogowie zetrą z powierzchni ziemi] jako Bodaj [tj. bodaj byś - ALK] źle zginą (C2v).

Pojawiający się w Terencjuszowych komediach motyw boga lub bogów z wierzeń starożytnych jest każdorazowo poddawany przez tłumacza wnikliwej analizie, która prowadzi do najbardziej prawomyślnego jego oddania bądź za pomocą wspomnianych ekwiwalentów, bądź odpowiedniej modyfikacji. Zwykle więc w zdaniach, w których jest mowa o bogach, Mateusz woli oddać formę liczby mnogiej bogowie za pomocą liczby pojedynczej Bóg, co jednoznacznie zwróci skojarzenia czytelnika w stronę Boga chrześcijańskiego: Diis habeo gratias. Bogu dziękuję. (C2v), Deos comprecare. Proś Boga. (L5v), Dii melius duint. Boże uchowaj. (O6v), Pro dii immortales... O mity Boże (O6v), Dii immortales... O Boże mocny... (R2). Nie inaczej należy interpretować podobny zabieg w odniesieniu do rezygnacji z nazwy proprialnej antycznego bóstwa: Proch Iupiter. O miły Boże. (E2), Iupiter magne... Boże wszechmogacy... (E5v).

Podobnych zabiegów znajdziemy w tekście Rozmówek znacznie więcej. Ciekawej transformacji dokonał autor również w odniesieniu do typowego dla omawianych komedii antycznych przyrównywania się szczęśliwie zakochanych młodzieńców do bogów: Deus sum, si hoc ita est. Analogicznie jak we wcześniej cytowanych fragmentach Rozmówek, również w tym wypadku Mateusz zgrabnie dobrał frazę oddającą sens oryginału, dyskretnie przesuwając semantyczne odwołania z kręgu politeistycznej religii starożytnej do kręgu terminologii chrześcijańskiej: Jakobym w niebie był, jeśli tak jest (Q6). Dostosował utarty zwrot być jak w niebie, który oznacza najwyższe szczęście, nawiązując do chrześcijańskiej wizji raju, miejsca wiecznej szczęśliwości. Wart zasygnalizowania jest jednak fakt, że nie zawsze autor uciekał się do podobnych rozwiązań formalnych. $\mathrm{W}$ odniesieniu do identycznego odwołania treściowego z komedii Heautontimorumenos: Deorum vitam adepti sumus Mateusz zrezygnował z przeróbek oryginału i przetłumaczył zdanie: Bogiśmy zostali (H4). Tu antyczne odniesienie pozostało w niezmienionej formie być może dlatego, że zastosowana liczba mnoga nie pozostawia żadnych złudzeń, natomiast w poprzednim fragmencie literalne tłumaczenie mogło budzić złe skojarzenia wśród odbiorców z kręgu kultury chrześcijańskiej.

Najpewniej na podobny opór współczesnego sobie odbiorcy trafiłby autor, gdyby dosłownie przetłumaczył mocne, ekspresywne przekleństwo Abi in malam crucem [= Idź na przeklęty krzyż], które w starożytności nawiązywało do zwyczajowej kary ukrzyżowania, wymierzanej niewolnikom i osobom niemającym rzymskiego obywatelstwa, dla XVI-wiecznego odbiorcy miało jednak zbyt silne powiązania z symboliką chrześcijańską. 
Z przedstawionych przykładów wynika, że XVI-wieczna sztuka przekładowa dopuszczała swobodne traktowanie oryginału i takie jego przetwarzanie, by oddało zamysł translatora, czyli odzwierciedlało realia otaczającego go świata, jak omówione $\mathrm{w}$ artykule - religijno-kulturowe. Zupełnie inny charakter miało tłumaczenie tekstów wiary, dla których tłumacz musiał znaleźć odpowiednie środki językowe, by zapewnić należyte oddanie i treści, i formy oryginału. Jako że wiek XVI stanowił złoty wiek różnego typu przekładów (teksty literackie i naukowe, poetyckie i prozatorskie, świeckie i religijne, podręczniki, kompendia, poradniki i in.), na pewno tłumacze mieli możliwość korzystania $\mathrm{z}$ różnych, wypracowanych przez innych translatorów, technik. Był to też okres, w którym pojawiło się w Europie wiele przekładów Pisma św. na języki wernakularne, stąd polscy tłumacze czerpali również inspiracje z metod i rozwiązań obcych, głównie czeskich. Skupiłam się zatem na złożoności problematyki przekładu w odniesieniu do tekstów dawnych, przedstawiając wybrane, przykładowe egzemplifikacje unaoczniające wpływ religii na wybory tłumacza w różnych aspektach. Dotyczyło to adekwatności dla przełożonych nazw pospolitych i własnych, dostosowania stylistycznego pod wpływem obcego systemu językowego, a także sposobów „ucieczki” przed rozdźwiękiem religijno-kulturowym między tekstem oryginalnym a kręgiem kulturowym translatora.

\section{Literatura}

Bieńkowska, D., 1999, Słownictwo i frazeologia w Psałterzu przełożonym przez ks. Jakuba Wujka (1594), Łódź.

Brzozowski, J., Filipowicz-Rudek M. (red.), 2009, Między oryginałem a przekładem XV. Obcość kulturowa jako wyzwanie dla tłumacza, Kraków.

Cieślikowa, A., 1996, „Jak» ocalić w tłumaczeniu « nazwy własne?”, [w:] Między oryginałem a przekładem II. Przekład, jego tworzenie się i wptyw, M. Filipowicz-Rudek, J. Konieczna-Twardzikowa (red.), Kraków, s. 311-320.

Cybulski, M., 1996, Staropolskie przekłady Psałterza [Rozprawy Komisji Językowej Łódzkiego Towarzystwa Naukowego 41, z. 2], Łódź.

Drozd, A., 1999, Arabskie teksty liturgiczne w przekładzie na język polski XVII wieku. Zagadnienia gramatyczne na materiale chutb świątecznych, Warszawa.

Kowalska, D., 2007, „Sposoby wprowadzania przytoczeń w przekładzie Nowego Testamentu J.J. Wujka z 1593 roku”, [w:] Z zagadnień leksykologii i leksykografi języków słowiańskich, J. Kamper-Warejko, I. Kaproń-Charzyńska (red.), Toruń, s. 143-152. 
Kulwicka-Kamińska, J., 2006, „Cechy wspólne piśmiennictwa Tatarów litewsko-polskich i kanonu tekstów scs. Geneza. Grafia. Ortografia", [w:] Varia, t. XIV, M. Olšiak (red.), Bratysława, s. 15-23.

Kwilecka, I., 2003a, „Biblia Leopolity i Biblia Brzeska. Tradycja a nowoczesność przekładu", [w:] Biblie staropolskie, I. Kwilecka (red.), Poznań, s. 29-37.

Kwilecka, I., 2003b, Studia nad staropolskimi przekładami Biblii, Poznań.

Lisowski, T., 2010, Sola Scriptura. Leksyka Nowego Testamentu Biblii Gdańskiej (1632) na tle porównawczym. Ujęcie kwantytatywno-dystrybucyjne, Poznań.

Luto-Kamińska, A., 2010, „Ex P. Terentii comediis Latinissimae colloquiorum formulae..." Mateusza z Kęt. Studium języka autora na tle polszczyzny XVI wieku, Warszawa.

Łapicz, Cz., Kitab Tatarów litewsko-polskich. Paleografia. Grafia. Język, Toruń 1986.

Moszyński, L., 2003, „Biblia Szymona Budnego. Charakterystyka przekładu”, [w:] Biblie staropolskie, I. Kwilecka (red.), Poznań, s. 41-48.

Pepłowski, F., 1978, „Zmiany językowo stylistyczne w Nowym Testamencie Szymona Budnego z 1574 r., [w:] Tekst. Język. Poetyka, M.R. Mayenowa (red.), Wrocław, s. 318-342.

Zarębski, R., 2004, Nazwy osobowe w polskich przekładach Nowego Testamentu, Łódź.

Zarębski, R., 2007, „Tłumaczenie obcych nazw geograficznych w dawnych i współczesnych polskich przekładach Nowego Testamentu", [w:] Studia nad słownictwem dawnym i współczesnym języków słowiańskich, J. Kamper-Warejko, I. Kaproń-Charzyńska (red.), Toruń, s. 113-123.

\section{The cultural (religious) identity and decisions of the translator}

\section{Summary}

This paper discusses the influence of cultural, especially religious, identity on the translator's work on the basis of texts rendered in the sixteenth century. The study investigates levels at which the translator interfered in the structure or meaning of the text. The texts analyzed can be distinctly divided into two groups. The first one comprises religious writings which had to be translated faithfully in order to render the meaning of the source text. In this case, the challenge for the translator was the lexis. On the one hand, due to the lack of equivalents of certain referents, the translator had to find a manner of rendering even those passages that described issues which were totally unfamiliar to the Polish culture. On the other hand, they had to decide 
how to translate proper names. As proper names often both denoted and symbolized certain concepts or items, the translator could try to either render them with Polish appellatives which would reflect their meaning or leave them in the source language. Moreover, the translation was also marked with the style of the source text and the use of language resources. In order to illustrate the issue, the paper presents examples of how sixteenth century translators dealt with finding appropriate linguistic devices to properly render both the meaning and the form of the source text.

The other, entirely different, type of translator's work was rendering a text which was significantly dissimilar to their culture and religion. In this respect, the paper includes an analysis of selected passages from the Latin textbook entitled ExP. Terentii comediis Latinissimae colloquiorum formulae..., which had the form of phrases and whose foreign part was based on excerpts from Terence's comedies. The study presents the translator's interference in the meaning in order to minimize the discrepancy between the ancient polytheistic religion of the source text and the Christian beliefs of the translator.

The examples presented in the paper lead to the conclusion that the translator's religion and cultural awareness had considerable influence on their conscious decisions to shape the target text in respect of lexis, grammar, style, and meaning.

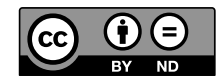

